\title{
The Response of Teff [Eragrostis teff (Zucc) Trotter] to Nitrogen Fertilizer Application and Row Spacing: A Review
}

\author{
Tamirat Wato* Tilahun Negash \\ College of Agriculture and Natural Resource, Department of Plant Science, Bonga University P.O. Box 334, \\ Bonga, Ethiopia
}

\begin{abstract}
SUMMARY
Teff [Eragrostis tef (Zucc) Trotter] is one of the most important crops in Ethiopia. It ranks the first among cereals in the country in area coverage and second in the production volume. Despite its importance, the production and productivity of this particular crop are highly constrained by several biotic and abiotic factors. Some of the factors contributing to the low yield of teff are low soil fertility and suboptimal use of mineral fertilizers in addition to weeds, old method of seed sowing, erratic rainfall distribution in lower altitudes, method of row planting, lack of high yielding cultivars, lodging, water-logging and late planting of the crop which exposes it to moisture stress. The productivity of teff is very low compared to other major cereal crops. On the other hand, under conditions where most growth requirements are available and inorganic matter rich soils, the application of fertilizers without knowing its fertility status causes yield and fertilizer losses. Likewise, producers do not give attention to teff row spacing, even if it has an advantage of shorter maturity days, highest plant height, highest panicle length, and the number of tillers and less lodging index percentages. Since, grain yield increased with the increase of plant height, panicle length and number of tillers per plant. Therefore, the optimum supply of nitrogen fertilizer and medium row spacing increased the grain yield of crops.
\end{abstract}

Keywords: teff; inter-row spacing; and grain yield

DOI: $10.7176 /$ ALST/78-02

Publication date: February $29^{\text {th }} 2020$

\section{INTRODUCTION}

Teff [Eragrostis teff (Zucc.) Trotter] is an indigenous and major staple food crop of Ethiopia. Teff crop is an allotetraploid $(2 \mathrm{n}=4 \mathrm{x}=40)$ crop belonging to the grass family Poaceae and it is among the major cereals of Ethiopia. It used to prepare a Spongy flatbread called "enjera" which is consumed by about $70 \%$ of the Ethiopian population (Arnold et al., 2008; Tamirat, 2019). Because of its wide ecological adaptation, hardiness, higher prices of both the grain and straw and highly preferred quality for "injera" making, farmers give it high priority both as food and cash crop (Abel, 2005). Teff has much or even more food value than the major grains such as wheat, barley, and maize. Teff grain contains $14-15 \%$ proteins, $11-33 \mathrm{mg}$ iron, $100-150 \mathrm{mg}$ calcium, and rich with potassium and phosphorus nutrients (National Academy, 1996). Teff has got many prospects outside of Ethiopia due to its gluten freeness, tolerance to biotic and abiotic stress, good animal feed and erosion control quality (Spaenij-Dekking et al., 2005; Tamirat, 2019). In Ethiopia, teff is cultivated in an area of about 3 million hectares and it contributes about $24.02 \%$ of the total grain crop areas (CSA, 2015). This makes teff the first among cereals in the country in area coverage. However, out of the total cereal grain produced, teff ranks second after maize sharing $17.57 \%$ (4.4 million tons), while maize ranks first with $26.76 \%$ ( 7.23 million tons) (CSA, 2015).

Teff is predominantly cultivated on sandy-loam to black clay soils. Moreover, teff withstands low moisture conditions and often considered as a rescue, crop that survives and grows well on residual soil moisture in the season when early planted crops (e.g. maize) fail due to low moisture (Abel, 2005; Tamirat, 2019). It is typically hand broadcasted on the field and in most cases, its seeds are left uncovered (Seyfu, 1997; Tamirat, 2019). Although teff is found in almost all cereal growing areas of Ethiopia, the major areas of production are Shewa, Gojam, Gonder, Wello, Wellega and central highlands of the country (Doris Piccinin, 2010; Tamirat, 2019). In the SNNPR agriculture is the backbone of the regional economy, contributing to about $73 \%$ of the regional GDP and more than $90 \%$ of the total employment (BoFED, 2010). Out of the total land size of the region 112,343.19 square kilometer, about 785,386.5 hectares of land had been used for the production of cereals and the estimated production was 11,172.4 million quintals (Tamirat, 2019). The land allocated in the region for the production of teff and wheat in the year 2007 was 238,539 and 137,295 hectares respectively. Moreover, the regional production of teff and wheat was 2,322.5 and 1,974.6 million quintals, respectively (CSA, 2015). Despite the aforementioned importance, its productivity is very low $\left(1.64 \mathrm{t} \mathrm{ha}^{-1}\right)$ compared to other major cereals (CSA, 2015). Some of the factors contributing to the low yield of teff are low soil fertility and suboptimal use of mineral fertilizers in addition to weeds, old method of seed sowing, erratic rainfall distribution in lower altitudes, method of row planting, lack of high yielding cultivars, lodging, water-logging and late planting of the crop which exposes it to moisture stress (Ermias et al., 2007; Tamirat, 2019).

On the other hand, under conditions where most growth requirements are available and inorganic matter 
rich soils, the application of fertilizers without knowing its fertility status causes yield and fertilizer losses (Tekalign et al., 2001; Tamirat, 2019). Even if producers do not give attention to teff row spacing, it has an advantage of shorter maturity days, highest plant height, highest panicle length, number of tillers and less lodging index percentages (Tamirat, 2019). Grain yield increased with the increase of plant height, panicle length and number of tillers per plant (Alemat et al., 2016). According to CSA (2015), the land area covered by teff and wheat in the Hadiya Zone was 8665.8 and 3564.6 hectares, respectively. The average land owned by teff and wheat producers was 2.93 and 3.15 hectares respectively. Limo is one of the districts which is the major producing of teff. The district has produced 93,164.6 quintals of teff annually. The productivity of teff in the district (10.75qts) is slightly lower than the national average (11.67qts) and higher than the regional average. Farmers in the Ethiopian highlands apply $\mathrm{N}$ fertilizer in the form of Urea at sub-optimal blanket rates mostly only once at the time of sowing, and this limits the potential productivity of cereal crops (Bekele et al., 2000; Tamirat, 2019). In general, blanket recommendations regardless of considering the physical and chemical properties of the soil as well as the application of full dose at one time, do not lead to an increase in the crop. Thus, the above-mentioned problems are real challenges in Ethiopia. Application of nitrogen and row spacing significantly influenced most of the plant phenology, growth parameters, yield and yield components of teff (Tamirat, 2019). This brief piece of work was, therefore, carried out with the objective to review the response of teff yield and yield components to nitrogen fertilizer and inter-row spacing.

\section{Teff Production and Its Constraint in Ethiopia}

Teff accounts for about a quarter of total cereal crop production in Ethiopia. According to USAID (2012), teff is currently the most expensive grain in Ethiopia because it requires labor-intensive harvesting and processing techniques, while it is producing the lowest yield per hectare of all cereal crops. Economic indicators unveil that teff is the most dominant cereal crop in Ethiopian agriculture. For instance, in the 2015 cropping season, it was estimated that a total of 7.23 million tons of teff has been produced on 3 million hectares of land (CSA, 2015). This is equivalent to $24 \%$ and $28 \%$ of the total cereal crop production and acreage in the country, respectively. Teff is Ethiopia's most important cereal crop, but its national average productivity is low (CSA, 2015). The general constraints of teff production are the method of sowing, weed, erratic rainfall, inter-row spacing, soil fertility status, environmental stress, unbalanced fertilization, lodging, the yield is shown to improve significantly on-station (Ermias et al., 2007). Field demonstrations of row spacing of teff showed that yields increase on average by $70 \%$ compared to the national average (ATA, 2013). Consequently, these new production technologies are being promoted by Ethiopian teff farmers on a large scale. Teff is resistant to extreme weather conditions, as it is able to grow under both drought and waterlogged conditions (Minten et al., 2013). Combined with its low vulnerability to pests and diseases, it is considered a low-risk crop (Fufa et al., 2011).

In Ethiopia, it is sown during the main summer rainy season between July and August, while harvesting is done in most cases in November and February. Seeds are broadcasted on a well-plowed soil and lightly covered with soil until germination. During the growing period, several weeding is often required (Assefa et al., 2011). Teff has enormous potential for growth as it has been given very little attention in research, development and public support (CSA, 2015). Additionally, it has remained an important crop to Ethiopian farmers for several reasons, namely: the price for its grain and straw are higher than other major cereals; the crop performs better than other cereals under moisture stress and waterlogged conditions; its grain can be stored for a long period of time without being attacked by weevils (Abel, 2005). Increased productivity is believed to contribute about $6 \%$ of the growth while about 5\% was attributed to expansion in the area cultivated to teff. So a reasonable conclusion that can be inferred from the literature is that the current or existing level of technology and factor endowment, there is a potential to boost agricultural output like teff production by improving the internal efficiency of the farmers through promoting new product innovation, education and providing credit facilities to the farmers, to mention a few.

To increase the production and productivity of teff different agricultural research centers released different varieties of teff (Kebebew et al, 2013). Among teff production constraints Environmental stress is the most important factor which affects crop production. According to Martin et al. (2010), only about 10\% of the world's arable land may be classified into a non-stress category. About $20 \%$ of the land is limited by mineral stress, $26 \%$ by drought stress and $15 \%$ by freezing stress (Blum and Jordan (1985). Modifying the environment for proper crop growth means the alleviation of environmental stresses through the current crop management practices (Rose, 2011). In semi-arid and arid areas, rainfall is inadequate, erratic, and non-uniform in distribution. Moreover, because of degradation and poor vegetation cover, soils in semi-arid and arid areas have low fertility with poor water holding capacity. In addition to the above-mentioned problems, weeds also compete with the food crops for the meager available moisture (Minten et al., 2013), besides, there are occasional outbreaks of pests and diseases. Teff is harvested very close to the ground because of the high value of the straw, leaving the soil bare for about half a year after harvest and exposing the ground further. Therefore, the loss of soil organic matter and physical erosion are major problems in some teff growing areas. Inorganic fertilizers are able to 
overcome some, but not all, of these deficiencies. According to Seyfu (1997), teff mostly grows on soils that are less fertile, have moisture deficit and mostly on waterlogged during the main rainy season, all of which limit the growth and yield of the crop. Moreover, the cultural broadcast sowing influences the availability of adequate space for each plant and consequently influences the uptake and utilization of resources such as nutrients. The low yield is due to low soil fertility status, which is a result of continuous cropping, overgrazing, soil erosion, and complete removal of field crop residues without any soil amelioration activities and low or no input of fertilizers (Seyfu, 1997; Tamirat, 2019).

\section{The Response of Teff to Row Spacing}

The work of Tareke and Nigusse (2008) at Debre Zeit Research Center showed a promising increase in grain yield of teff which was four-fold as compared to the control $(1036 \mathrm{~kg} / \mathrm{ha})$ by using $20 \mathrm{~cm} \mathrm{spacing}$ between rows with a decreased seed rate of $5 \mathrm{~kg} / \mathrm{ha}$. Fikere mariam et al. (2014), at the Adet Agricultural Research Center also showed that except for the biological yield, row spacing was significantly influenced plant height, tiller number biological yield, and grain yield. Relatively the shortest plant heights $(125.5 \mathrm{~cm}$ and $124.7 \mathrm{~cm})$ were recorded from the two spacing extremes $15 \mathrm{~cm}$ and $30 \mathrm{~cm}$ respectively, while the tallest plants $(129.5 \mathrm{~cm}$ and $129.1 \mathrm{~cm})$ were from relatively medium row spacing $20 \mathrm{~cm}$ and $24 \mathrm{~cm}$ (Ali et al., 2011). However, all were superior over the control (broadcasting) in terms of plant height (Fikere mariam et al., 2014; Tamirat, 2019). Tiller number was highly significant for row spacing (Fikere mariam et al., 2014).

Broadcast planting gave the lowest tiller number compared to the transplanting of various row spacing. This is due to better access to space, nutrients, water, and light in wider spacing than the narrow spacing between rows. Since teff straw has comparable importance to its grain yield, highlighting the result of biomass yield got logical attention it was not statistically significant for row spacing. Relatively biomass yield was higher for narrower spacing $(15 \mathrm{~cm})$ than wider spacing since more plant stands per unit area (Fikere mariam et al., 2014). It also reduces the seed rate from the broadcasting method that a farmer uses $25-50 \mathrm{~kg} / \mathrm{ha}$ teff but in the new row drilling method $2-2.5 \mathrm{~kg} / \mathrm{ha}$. The highest grain yield of $24.4 \mathrm{Q} /$ ha was obtained when a $15 \mathrm{~cm}$ distance between rows was used. So the optimum spacing between rows for transplanting teff is found to be $15 \mathrm{~cm}$ (Fikere mariam et al., 2014). Abraham (2014) showed that the row sowing method had significant effects on growth parameters, yield and yield components of teff crop in terms of plant height, total tiller, fertile tiller, and grain yield. Even if, it is difficult to make any definite conclusion based on the experiment of only one season and one location, the author tentatively concluded that a seed rate at $25 \mathrm{~kg} / \mathrm{ha}$ using row planting method can be suggested for the production of high grain and straw yield of teff on vertisols of Ad'a plains in Debre Zeit area. The present results best bit the practical importance of adequate row spacing for grain yield of teff transplant planting method and suggest that application of $15 \mathrm{~cm}$ row spacing of $15 \mathrm{~cm}$ plant spacing and 15 to $30 \mathrm{~cm}$ row spacing of $15 \mathrm{~cm}$ plant spacing were recommended for both black and red soil conditions, respectively (Fikere mariam et al., 2014).

An experiment conducted in 2012/13 cropping season in two locations at Axum and Adet, Northern Ethiopia (Alemat et al., 2016) indicates, the transplanted treatments had shorter maturity days, highest plant height, highest panicle length, and a number of tillers and less lodging index percentages. In addition to this, the transplanted treatments $(20 \mathrm{~cm} * 15 \mathrm{~cm}$ spacing) and $(20 \mathrm{~cm} * 10 \mathrm{~cm}$ spacing) which is similar to drilling the seed in a row scored the highest grain yield and biomass yield at Adet and Axum locations. Grain yield increased with the increase of plant height, panicle length and number of tillers per plant (Alemat et al., 2016). In contrast, grain yield decreased with the increase of days to maturity and lodging index (Alemat et al., 2016; Tamirat, 2019). Hence based on these results it could be recommended that, for better teff grain and biomass yield and for improved grain quality of the crop, teff should be planted in a row spacing of $20 \mathrm{~cm}$ and plant spacing of $15 \mathrm{~cm}-$ $10 \mathrm{~cm}$ (Alemat et al., 2016).

\section{Crop Response to Nitrogen Fertilizer}

Nitrogen $(\mathrm{N})$ is one of the most yield-limiting nutrients for crop production in the world (Amer et al., 2016). It is also the nutrient element applied in the largest quantity for most annual crops (Huber and Thompson, 2007; Saberioon and Gholizadeh, 2015). The increase in the use of nitrogen (N) fertilizers for enhancing agricultural production has been under consideration for the last fifty years (Hirel et al., 2007). The amount of nitrogen required by crop depends on the type of small grain, the previous crop in the rotation, the soil type, weather conditions, supply of residual, nitrogen fertilizer management and cultural practices during the growing season. Crop response to nitrogen fertilizer varies with the rate and time of application in relation to plant development (Temesgen, 2001). Barley, oat, and wheat require a different amount of nitrogen and the amount depends on the yield potential of the crop and the intended use (grain production requires higher nitrogen levels than forage production) (Temesgen, 2001).

Nitrogen affects crop performance through its ability to determine photosynthetic capacity. Application of nitrogen at the onset of stem elongation greatly stimulated leaf area growth, which resulted in significantly greater assimilation capacity, both before and after flowering. Increases in grain yield achieved through 
improved grain indices have, however, often outstripped improvements in the uptake and partitioning of $\mathrm{N}$ to grain and also $\mathrm{N}$ stimulates tillering probably due to its effect on cytokinin synthesis (Kebebew et al, 2013). The presence of $\mathrm{N}$ in excess promotes the development of the aerial organs with relatively poor root growth. Synthesis of proteins and the formation of new tissues are stimulated, and thus carbohydrates of high molecular weight are synthesized in insufficient amounts, resulting in abundant dark green (high chlorophyll) tissues of soft consistency. This increases the risk of lodging and reduces the plant's resistance to harsh climatic conditions and to foliar diseases and insect predation. A non-limited supply of $\mathrm{N}$ also extends the growth cycle (extends the life span of a leaf), delaying maturity, and often reduces the quality of the harvestable products due to loss of chlorophyll during grain filling stage (Yang et al., 2000).

\section{Effect of $\mathbf{N}$-fertilizer on Crop Yield}

Nitrogen plays a central role in plant biochemistry being an essential constituent of the cell wall, cytoplasmic protein, nucleic acids, chlorophyll and other cell components (Temesgen, 2001). As a result, deficiency in the supply of $\mathrm{N}$ has a profound effect on crop growth, development and can lead to a total loss of grain yield in extreme cases (Fikere mariam et al., 2014).). The nitrogen exerts its influence on crop growth in various ways. It promotes rapid growth and increases tiller production. High $\mathrm{N}$ rates stimulate root and leaf growth and thereby increase photosynthetic activity and growth (Evans, 1993). Nitrogen plays a predominant role among the soil nutrients in crop production (Temesgen, 2001). The number of nutrients required to optimize or sustain crop production depends on the inherent capacity of the soil to supply adequate levels of nutrients to the growing plants, the yield potential of the crops, the variety is grown and the availability and cost of fertilizers. Among macronutrients, $\mathrm{N}$ is ranked first in limiting sustainable crop production (Legesse, 2004). In growing high yielder teff varieties, $\mathrm{N}$ deficiency limits production more often than any other factor (Legesse, 2004). $\mathrm{N}$ helps the production of more straw while $\mathrm{P}$ ensured good grain production, whereas $\mathrm{K}$ was found to have a minor effect on teff production (Temesgen, 2001).

Excess $\mathrm{N}$ supply causes higher photosynthetic activity and vigorous vegetative growth, which is disadvantageous early in the growing season when moisture limits plant growth, and is accompanied by weak stem. Dark green color, low product quality, delay in maturity, increase in susceptibility to lodging, insect pests and diseases (especially fungal diseases), and build-up of nitrite which is harmful to foliage and straw, feed are common effects of excess $\mathrm{N}$ application in teff (Temesgen, 2001; Legesse, 2004). Nitrogen is the most mobile element in the soil (Seyfu, 1997). It is widely spread in nature, and the atmosphere is the main reservoir for it. The soil accounts only for a small fraction of lithospheric N, of which small proportion is directly available to plants in the form of $\mathrm{NO}_{3}$ - or $\mathrm{NH}_{4}+$ ion (Seyfu, 1997). The preference of plants for either $\mathrm{NO}_{3}-$ or $\mathrm{NH}_{4}+$ is determined by the age and type of a plant, the environment, and other factors. Cereals, sugar beets and ryegrass use either form of $\mathrm{N}$ (Kebebew et al, 2013). The application of $\mathrm{N}$ usually promotes the uptake of other nutrients such as phosphorus. The effect of $\mathrm{NH} 4+$ containing fertilizer in enhancing $\mathrm{P}$ uptake was explained by the increased solubility of soil $\mathrm{P}$, increased root growth in the fertilized zone, and the increased metabolic activity of roots (Kebebew et al, 2013).

\section{Effects of Nitrogen Fertilizer Rates on Yield and Yield Components}

Fertilizer management is an important part of the overall management package target towards realizing a higher yield (Bayoumi and El- Demardash, 2008). The use of low rates of high-yielding modern crop cultivars, especially by farmers in developing countries, is another cause of $\mathrm{N}$ deficiency (Fageria et al., 2003). In developing countries, intensive agricultural production systems have increased the use of $\mathrm{N}$ fertilizer in efforts to produce and sustain high crop yields (Fageria et al., 2003; Tamirat, 2019). Consequently, N losses in the environment have also increased (Schmied et al., 2000). Even with the continuing research on $\mathrm{N}$ management, average worldwide $\mathrm{N}$ use efficiencies (NUE) are reported to be around 50\% (Collins et al., 2007). Nitrogen fertilization management offers the opportunity of increasing grain protein content and quality. Eyvazi et al., (2010) reported that increased use of fertilizer nitrogen $(\mathrm{N})$ in agricultural production has however raised concerns because the $\mathrm{N}$ surplus is at risk of leaving the plant-soil system and thereby causing environmental contamination. Liberal application of nitrogen fertilizer results in nitrate accumulation in groundwater, due to nitrate leaching (Seyfu, 1997; Tamirat, 2019). Especially cereals being a shallow-rooted crop with the domain root zone at $20 \mathrm{~cm}$ below the soil surface, can lead to considerable nitrate loss by leaching under irrigated or high rainfall conditions (Ren et al., 2003), and can thus lead to human and environmental health problems. This is in addition to increased costs associated with the manufacture and distribution of $\mathrm{N}$ fertilizer (Alizadeh, 2006). Haftamu et al. (2009) and Tamirat (2019) reported that the nitrogen fertilizer rate caused a significant effect on yield attributes.

Teff plants with higher plant height $(125.02 \mathrm{~cm})$ and panicle longest $(44.5 \mathrm{~cm})$ were found by applying a high amount of $\mathrm{N}$ fertilizer $(97.5 \mathrm{~kg} \mathrm{~N} / \mathrm{ha}$ ) (Tamirat, 2019). This is because high nitrogen usually favors vegetative growth of teff which results in taller teff plants having relatively greater panicle length (Tamirat, 
2019). Similarly, the highest biomass and grain yields were obtained by applying $97.5 \mathrm{~kg} \mathrm{~N} / \mathrm{ha}$ (Tamirat, 2019). Thus, the application of nitrogen improves various yield-related traits like 1000-grain weight, more productive tillers, number of spikes per unit area, number of grains per spike and biological yield (Warraich et al., 2002) thus resulting in higher yields. Fageria et al. (2011) also reported that plant height, flag leaf area, and tillers number and dry weight per unit area of wheat were increased with increasing $\mathrm{N}$ rates.

\section{Interaction between Row Spacing and Nitrogen on Teff yield}

Nitrogen and spacing are important factors in determining teff grain yield. High yield of teff is usually obtained by increasing nitrogen applications and low planting. Grain yield of teff increases with the increasing number of hills per unit area as long as there is space in the cultivated field (Tamirat, 2019). When the planting density exceeds the best level, competition among plants for the light above ground and for nutrients belowground becomes severe. Accordingly, the growth of plants is limited and hence, the economic yield of crops decreases. If mutual shedding/overlapping is the limiting factor for nitrogen response, nitrogen response can be improved by giving individual plants more light by increasing the space between them (Ali et al., 2011). The optimum amount of nitrogen and planting density differs with varieties or genotypes. Many workers reported that the nitrogen level and the degree of spacing determine the growth of cereal crops and modify their characters, which are plant height, heading time, tiller number, panicle length, 1000 kernel weight and yield. Generally, varietal differences in the response to nitrogen and spacing or both have been recognized in teff (Martin et al., 2010). Adaptability to heavy fertilization or dense planting or both relate to the physiological characters controlling the abilities for absorption and assimilation of nitrogen, photosynthesis, translocation, and storage of its products, growth of leaves, the activity of the roots and resistance to lodging and disease (Kebebew et al., 2013). Amin et al. (2004) reported the interaction effect of plant density and fertilizer (N) dose was found non-significant.

\section{FUTURE PERSPECTIVES}

The production and productivity of teff is very low compared to other major cereal crops. So in order to increase the productivity of the crop, the following should be done.

1. Teff should be planted or sown in a row. This is due to better access to space, nutrients, water, and light in wider spacing than the narrow spacing between rows.

2. The rate and time of application of nitrogen fertilizer should be recommended for all areas where teff is cultivated. Since blanket recommendations irrespective of considering the physical and chemical properties of the soil as well as the application of full dose at one time, do not lead to an increase in the teff yield.

\section{REFERENCES}

Abel Debebe. (2005). Performance of $\mathrm{F}_{4}$ progenies and Association among yield and yield-related traits. Agricultural Research, 34(2): 279-285.

Abraham R., Nigussie D., \& Kebebew A. (2014). Evaluation of seed rates and sowing methods on growth, yield and yield attributes of Tef [Eragrostis tef (Zucc.)] Trotter] in Ad'a district, east Showa, Ethiopia. Journal of Biology, Agriculture and Health care, (4/23). 166-173.

Alemat E, Kidu G., Mihreteab H. \& Haftamu H. (2016). Determination of the Optimum Population Density of Seedlings during Transplanting for the Productivity Improvement of Tef [Eragrostis tef (Zucc.)] Trotter] in the Central zone of Tigray, Ethiopia. Journal of Biology, Agriculture, and Healthcare, 6(1).

Ali M. A. Abouzar. Saeid B. Hashem A. (2011). Effect of different levels of nitrogen and plant spacing on yield, yield components and physiological indices in high-yield rice (number 843). American-Eurasian Journal of Agricultural and Environment Science, 10(5):893 - 900.

Alizadeh, K, Ghadeai, J. (2006). Variation of nitrogen uptake efficiency in local landraces of wheat in Mahabad Iran. Journal of Agriculture and Soc. Sci., 18:122-124.

Amer, M.M.; M.A. Aiad; \& G.M.A. El-Sanat. (2016). Impact of Different Soil Moisture Depletion, Nitrogen and Biofertilizer Application Levels on Yield-Water Productivity of Wheat and Sunflower at North Delta. Int. J. Adv. Res: 4(8), 2180-2191. DOI: 10.21474/IJAR01/1436.

Arnold Dijkstra \& Hogeschool Van Hall-Larenstein. (2008). Survey on the nutritional and health aspects of tef (Eragrostis tef) Instituto Tecnológico de Costa Rica, Sede Central Apdo. 159-7050 Cartago. Costa Rica.

Bayoumi, TY, El- Demardash. (2008). Influence of nitrogen application on grain yield and end-use quality in segregating generations of bread wheat (Triticum aestivum L). Africa Journal. Biol. Res., 2: 132-140.

Bekele, HK., Verkuijl, H., Mwangi, W., Tanner, D. (2000). Adoption of Improved Wheat Technologies in Adaba and Dodola Woredas of the Bale Highlands, Ethiopia. Second National Maize and Wheat Workshop. November 12-16; Addis Ababa. International Maize and Wheat Improvement Center) and Ethiopian Agricultural Research Organization (EARO). Addis Ababa, Ethiopia. 
BoFED (Bureau of Finance \& Economic Development). (2010). Southern Nations \& Nationalities Peoples' (Snnprg) Regional Government Pefa Assessment Report.

Collins, H. P., Delgado, J. A., Alva, A. K., Follett, R. F. (2007). Use of nitrogen-15 isotopic techniques to estimate nitrogen cycling from a mustard cover crop to teff. Agronomy Journal: 99: 27-35.

CSA (Central Statistical Authority). (2015). Report on area and production of crops: Central Statistical Agency. Statistical Bulletin, Volume I: 532, Addis Ababa.

Ermias A, Akalu T, Alemayehu A, Melaku W. \& Tilahun T. (2007) (eds). Proceedings of the 1st Annual Regional Conference on Completed Crop Research Activities, 14-17 August 2006. Amhara Regional Agricultural Research Institute. Bahir Dar, Ethiopia.

Evans, L.T. (1993). Crop evolution, adaptation and yield $1^{\text {st }}$ ed. Cambridge University Press, New York, Port Chester. USA.

Fageria, N. K., Baligar, V. C. (2003). Methodology for evaluation of lowland rice genotypes for nitrogen use efficiency. Journal Plant Nutrient: 26:1315-1333

Fageria, N.K., A.B. Dos Santos, A.M. Coelho. (2011). Growth, yield and yield components of lowland rice as influenced by ammonium sulfate and urea fertilization. Journal of Plant Nutrition: 34:371-386.

Fikremariam A., Yayeh B., Mitiku A., Minale L. \& Wudu G. (2014). Row Spacing and Fertilizer Rate on Yield and Yield Components of Tef Eragrostis Teff (Zucc.) Trotter) under Transplanting Planting Method. Journal of Biology, Agriculture, and Healthcare. 4 (15).

Food and Agriculture Organization of the United Nations (FAO). (2000). Guidelines on integrated soil and nutrient management and conservation for FFS. Land and Plant Nutrition Management Service Land and Water Development Division Rome, 2000.

Haftamu G., Mitiku H., Charles F. (2009). Tillage Frequency, Soil Compaction and N-fertilizer Rate Effects on Yield of Tef [Eragrostis tef (Zucc.) Trotter] in Central Zone of Tigray, Northern Ethiopia Thesis presented to Mekelle University, Ethiopia.

Hirel, B., Gouis, J. Le, Ney, B. \& Gallais A. (2007). The challenge of improving nitrogen use efficiency in crop plants: towards a more central role for genetic variability and quantitative genetics within integrated approaches. Journal of Experimental Botany 58: 2369-2387.

Huber, D. M., Thompson, I. A. (2007). Nitrogen and plant disease. 31-44. In: Mineral nutrition and plant disease, L. E. Datnoff, W. H. Elmer, and D. M. Huber, Eds., St. Paul, MN: The American Psychopathological society. International Food Policy Research Institute / Ethiopia Strategy Support Program II.

J. Eyvazi, H. Irannejad, M. H. Kianmehr, M. Esmaeili, Q. A. Akbari \& R. N. Onwonga. (2010). The effect of Pellet fertilizer application on Wheat Yield and its Components. International Research Journal of Plant Science: Vol. 1(6) pp. 163-171.

Kebebew A, Solomon Ch. \& Zerihun T. (2013) (eds.). Achievements and Prospects of Tef Improvement; Proceedings of the Second International Workshop, November 7-9, 2011, Debre Zeit, Ethiopia. Research Ethiopian Institute of Agricultural, Addis Ababa, Ethiopia; Institute of Plant Sciences, University of Bern, Switzerland. Printed at Stämpfli AG, 3001 Bern, Switzerland. ISBN: 978-3-033-03818-9.

Legesse A. (2004). The response of tef [Eragrostis tef (Zucc.) Trotter] to applied nitrogen and phosphorus in Sirinka, North Eastern Ethiopia. M.Sc Thesis, Alemaya University, Alemaya, Ethiopia.

M. Seberioon \& A. Gholizadeh. (2015). Application of Multispectral Cameras for Estimating Nitrogen and Grain Yield in Paddy Fields. DOI: 10.13140/RG.2.1.3463.6960

Minten, B., Seneshaw, T., Ermias, E. \& Tadesse, K. (2013). Ethiopia's Value Chains on the Move: The Case of Tef. Ethiopian Strategic Support Program, Working Paper 52. Addis Ababa, Ethiopia.

NAS (National Academy of Science). (1996). Lost crops of Africa volume 1, Grains. BOSTID National Research Council. National Academy Press. Washington, D.C of underutilized and neglected crops. Biodiversity institute Addis Ababa, Ethiopia.

Seyfu Ketema. (1997). Teff [Eragrostis teff (Zucc.) Trotter] Promoting the conservation and use of under-utilized and neglected crops Biodiversity Institute, Addis Ababa SNNPR Livelihood Zone Report. Population by Livelihood Zone and Kebele, Gamo Gofa Zone, Ethiopia.

Tamirat W. (2019). Effects of Nitrogen Fertilizer Rate and Inter-row Spacing on Yield and Yield Components of Teff [Eragrostis teff (Zucc.) Trotter] in Limo District, Southern Ethiopia. International Journal of Plant \& Soil Science. 31(3):1-12.

Tareke B. \& Nigusse Z. (2008). Results in a trial of System of teff Intensification (STI) at Debre Zeit. In: Proceedings of Annual Research Review Workshop, pp. 16- 17, Debre Zeit, Ethiopia.

Temesgen K. (2001). The effect of sowing date and nitrogen fertilizer on yield and yield traits of tef [Eragrostis tef (Zucc.) Trotter]. M.Sc. Thesis. Haremaya University of Agriculture, Ethiopia pp.: 30-36.

Warraich, EA, Ahmad, N. S.M.A Basra \& Afzal, I. (2002). Effect of nitrogen on source-sink relationship in wheat. Int. Journal. Agri. Biol: 4: 300-302. 
Yang, J., Zhang, Z., Huang, Q., Zhu L. (2000). Remobilization of carbon reserves is improved by controlled soildrying during grain filling of wheat. Crop Science. 40: 1645- 1655. 